\title{
Disadvantages of Imperfect Competition in Solar Energy Collector Markets and Policy Recommendations
}

\author{
Hakan Acaroğlu ${ }^{1} \&$ M. Celalettin Baykul ${ }^{2}$ \\ ${ }^{1}$ Department of Economics, Eskisehir Osmangazi University, Eskisehir, Turkey \\ ${ }^{2}$ Department of Physics, Eskisehir Osmangazi University, Eskisehir, Turkey \\ Correspondence: Hakan Acaroğlu, Department of Economics, Faculty of Economics and Administrative Sciences, \\ Eskisehir Osmangazi University, Eskisehir 26480, Turkey. Tel: 90-222-239-3750/1750. \\ Received: March 4, 2016 \\ Accepted: March 20, 2016 \\ Online Published: April 5, 2016 \\ doi:10.5430/rwe.v7n1p45 \\ URL: http://dx.doi.org/10.5430/rwe.v7n1p45
}

An earlier version of this manuscript was presented as a "poster" at SOLARTR 2014 Conference \& Exhibition 19 21 November 2014, Swiss Otel Büyük Efes, İzmir, Turkey.

\begin{abstract}
This paper's aim is to show how the features of renewables in terms of both the product and the sector considering solar energy flat plate collector market should be. We focus on a technological device: flat plate solar collector, designed as solution for energy problems of Turkey. We introduce the device and define the market's structure economically. We show the problems of the sector and the disadvantages of market. We offer a solution based on economic policy regarding what can be done for the future for this product and the related sector in the Turkish Markets.
\end{abstract}

Keywords: solar energy, flat plate solar collectors, competitive markets

\section{Introduction}

Turkey has insufficient energy supply as is the case for many developing nations. As a renewable form, solar energy and the application of flat plate collectors for household use can address this problem. Utilizing local technology and using national resources can be an effective strategy for overcoming the insufficient energy supply; however, this is an extra burden for the market structure and its competitiveness level.

There are barriers for new entrants to enter flat plate collector market. The first important barrier is information insufficiency of investors about the market. The second important barrier is the imperfect competition in the flat plate collector market in which public agencies critically influence the market prices. The domination of public sector and the lack of current market laws in this market prevent prices to reach investors as a feedback. In other words, markets become far away from their perfect competitive characteristics which they need to have as ideally. The new investors find it risky to invest in this sector. In order to overcome this problem, the weight of the public sector needs to be balanced by the private sector. Thus, the controlling and monitoring mechanism of existing competition by institutions such as Republic of Turkey Energy Market Regulatory Authority (EPDK) becomes extremely important.

Besides these factors, for a healthy functioning of the solar collectors market is needed to avoid from asymmetric information. It is necessary to be open in competition. And the market mechanism should be independent from politics in its own decisions.

We will discuss some related concepts about renewable solar energy in the following section. These titles are of importance to solar energy, renewable solar energy policies, its economics and current situation of market in Turkey. The subtitles also include subjects such as definition and technical features of solar flat plate collectors, the current technology and the competition type of market in Turkey.

\section{Importance of Solar Energy}

Energy is one of the important inputs for production communities. In addition, producing energy with a system by which societies attain maximum level economic utility can be seen as one of development standards for countries. However, there are many ways to produce energy without disturbing the balance of ecosystem. Solar energy is one of 
those energy types. Besides, concerning ecological balance, solar energy systems supply energy saving compared to conventional energy systems. Hot water is obtained by absorbing solar radiation on the absorber of a solar collector. These systems can be defined in details as follows.

\subsection{Definition of Solar Flat Plate Collectors}

Solar energy systems are solar cells which directly transform solar energy to electrical energy, solar flat plate collectors which transform solar energy to heat, etc. Solar energy systems result in energy saving according to conventional systems by preserving ecological balance. In order to obtain hot water using solar energy, the most frequently used system one is a solar flat-plate collector among these systems (Baykul, 1987). This energy system has some costs associated with installation, credit and annual maintenance costs for residences, firms, factories and etc... But once it is set up, then it will have many ecological advantages for the region and the world since fuel is no more used. Moreover users save money they spend on fuel and fuel tax.

\subsection{Definition of Renewable Solar Energy Policies, and Its Economics}

Governments achieve maximum utility through development strategies based on renewable energy resources. Turkey has also need various strategies for using renewable energy resources effectively in certain regions of the country. Solar energy is one of those alternative resources.

The studies in the world that are related to solar energy systems of policy, market and employment can be given as; Kancs and Wohlgemunt (2008), Han and et al. (2010), Timilsina and et al (2012), Manley and et al (2013). It is possible to cite examples about studies related to solar energy systems and policies. Cetin and Egrican (2011), emphasizing on solar energy as an indispensable resource for world countries, show that there can be economically positive effects on employment in Turkey. And they defend that this can be achieved by supporting government tariff policies about solar energy. According to UCTEA's report (2012); foreign dependency is increased because of governments' privatization policies. As a result, the effectiveness of public is decreased and energy prices are increased. As a social reflection consequence of this situation, it is seen that, the low level income families' energy consumption availabilities is limited according to modern life's conditions. According to UCTEA's data; Turkey face with the problems of foreign dependency with more than $\% 70$ consumption on primary energy and $\% 60$ electricity productions. Solving this problem can only possible by decreasing foreign purchasing receipts that reach to 65 billion dollars in 2012 and as a consequence to able to reach the energy that is cheap, continuous, reliable and sustainable. In addition to decreasing harm of energy investments to environment at a minimum level, the necessity of designing and applying the policies and programs of local production of energy systems and equipment are critical as stated in the report.

\subsubsection{Local Technology Situation}

Solar energy systems are not only used by obtaining heat energy from solar insolation through recycling. The system which is called photovoltaic solar cells recycles solar energy directly to electrical energy. As Bardhan et al., (2014, p.54) has stated, these systems are generally accepted worldwide. The applications of these systems especially have been implemented in U.S.. Turkey has enough potential for solar energy. Figure 1 shows the total solar radiation levels for all cities in Turkey.

The maximum obtained annual solar radiation in Germany is $1,050 \mathrm{KWh} / \mathrm{m}^{2}$ per year. Although the values in Figure 1 are greater than the abovementioned value for Germany, Germany is making large investments in solar energy. Thus, although Turkey's solar energy potential exceeds that of Germany, very low limit (only 0,00002\%) of Turkey's potential is being used. And the total final energy production and consumption in Turkey for solar energy is below \%1,05 among the other energy sources (Bilgen, 2008, p.380; IEA, 2005, MENR, 2005). For this reason, the subject of solving increased energy deficit by obtaining electrical energy from solar energy and using this in appropriate circumstances becomes very crucial. 


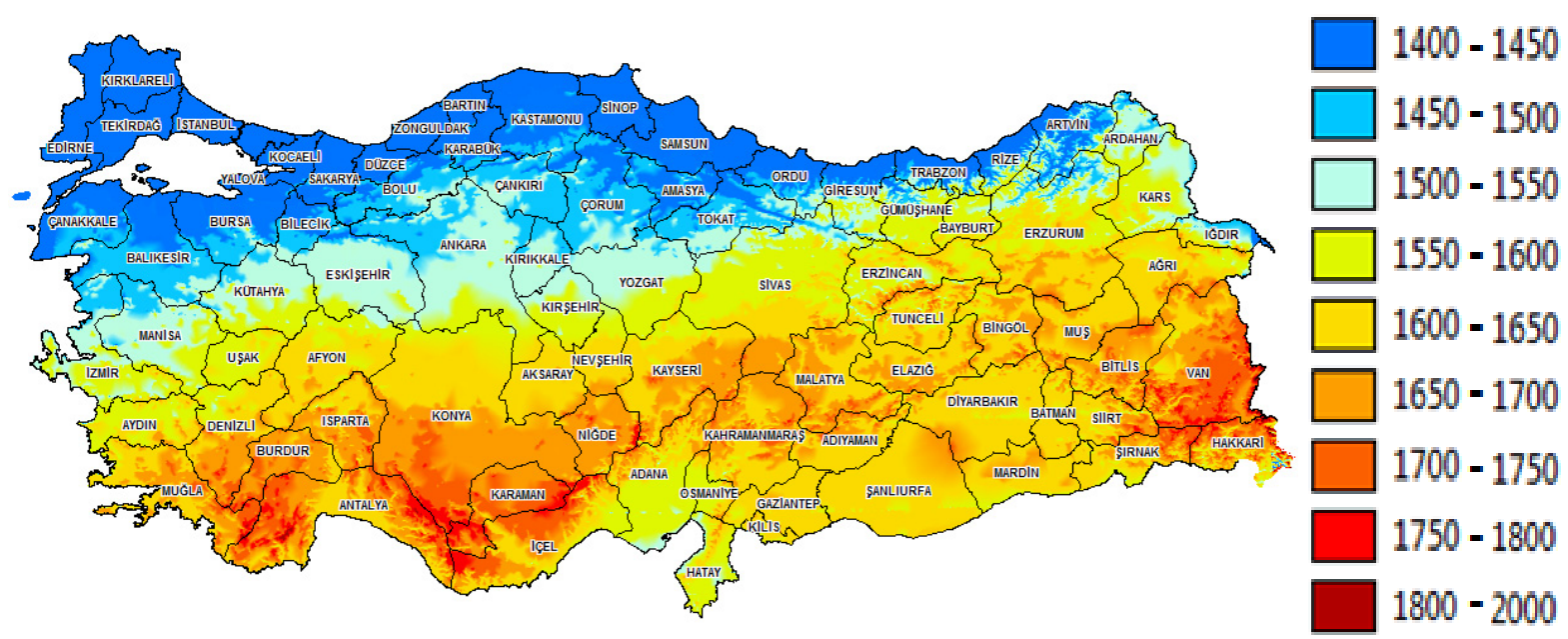

Figure 1. Solar energy potential atlas for Turkey; total solar radiation $\left(\mathrm{Kwh} / \mathrm{m}^{2}\right.$-year)

Source: YEGM http://www.eie.gov.tr/MyCalculator/Default.aspx

\subsubsection{Competition Type of the Market}

Competition type of the market is presented under two titles; a main title and a subtitle. The main title is competitive market, and the subtitle is perfect competition markets. It's better to mention that the characteristics of the solar energy market in Turkey are far away from the perfect competition than the desired level. This study explains the reasons behind lack of perfect competition. But before that let's explain what we understand by competitive markets.

\subsubsection{Competitive Markets}

A competitive market has two main properties. The first condition requires many sellers and buyers interacting each other. The second condition suggests that the goods in the market offered by different sellers are almost same at least in quality. As a consequence of these properties, one single seller or buyer can not have any effect on the prices in that market. So, it can be said that everyone in the market (both the sellers and buyers) take the price as it has exactly given to them (called as price takers), that is determined by market conditions itself (Mankiw, 2011).

\subsubsection{Perfect Competition Markets}

In addition to the two conditions above for competition, there is a third condition sometimes thought to characterize perfectly competitive markets: Firms can freely enter or exit the market. If, for instance, anyone can decide to start producing a solar flat plate collector business and if there is any entrepreneur who may decide to leave the renewable energy business, then the condition would be satisfied by the solar energy industry. However, this property of competitive market generally becomes important when the long-run analyses that help to shape the markets structure are made (Mankiw, 2011).

\subsection{Imperfect Competition and Current Situation of the Market in Turkey}

A firm is not competitive if it is the only seller of its product and also if this product does not have any close substitute. These kinds of markets are called monopoly. Entering freely to the market is the main obstacle in this situation. Therefore, competition loses its meaning (Mankiw, 2011). We can see government regulations in these markets with some subventions and some tax regulations. At the beginning, these regulations can be an advantage for the production of technological goods but however, they may be a barrier for competition in the long run. And if the government does not give enough support and encouragement, the production process can be affected negatively.

One of the important problems of this sector is that solar energy potential is not used in Turkey. Until the last few years, solar energy was identified by water heating, but this situation started to change with the photovoltaic becomes common in the markets. However, the situation is still far away from the targeted market capacity. For this reason, there is not sufficient knowledge about market, (as an example; the smooth industrial design that are used in cooperative apartment houses or factories built by State Housing Agency (TOKİ) are not well known) it is not given enough subsidies, encouragement and discount to the sector. On the other hand, there are also some positive examples. In the concept of ORKÖY project, Ministry of Environment and Urban Planning advised solar energy to avoid burning trees and harming forests in rural areas. And this improved market. If this project is applied nationwide in savanna 
villages, a solar energy market can be built in all villages of Anatolia by encouraging residents (Gündergi, 2013).

\section{Market Characteristics, Barriers and Problems of the Sector}

This title involves three subtitles: Features of the sector (size and characteristics), market disadvantages and market failures.

\subsection{Size and Characteristics of the Sector}

The solar radiation is $3.6 \mathrm{kWh} / \mathrm{m}^{2}$-day and total radiation duration is around 2,640 hour in average annually in Turkey. This radiation amount is enough for providing appropriate energy in applications using solar resources (Bilgen et al., 2008, p.386). Approximately, eight million meter square solar collectors were set up in 2004. And it is estimated that the solar energy production in the same year was around 0.290 million ton of oil equivalent (mtoe) (Kaygusuz \& Toklu, 2012).

Considerable amount of attention has been attracted on the energy studies and energy sources in Turkey recently (Yarbay et al., 2011). Yarbay et al. give some information about solar energy market potential of Turkey as follows. For its locational advantages, Turkey seems to have high solar energy potential (Rizwan et al., 2010). In spite of this high potential, solar energy is not now widely used, except for flat-plate solar collectors. The usage purpose of the solar flat-plate collectors is hot water production domestically and these collectors are mostly seen in coastal regions (Bilgen et al., 2008, p.387). On the other hand, solar collectors and photovoltaics (PV) can be used for electricity generation. But it is known that while PVs have expensive set up costs, collectors have cheap installing costs. Hence, the usage of solar collectors is more economical than PVs. An installed photo voltaic capacity of $300 \mathrm{~kW}$ has a wide spread use in Turkey's various buildings, institutions and research associations (Özgür, 2008, p.2351). It is known that in many residential areas solar based electricity seems to be more economical than grid supply. Especially, in holiday villages PV market is a potential along with long coastal areas (Ilk1lıç et al., 2011).

Solar energy is one of the important renewable energy resources. In addition, this source hasn't become nationwide even commercially in Turkey, which has high solar energy potential. Flat plate solar collectors (Thermosyphon-type) have been used since 1950 in Turkey. Moreover, approximately 30\% of set up systems are still same type. These types of collectors have a surface area changing between 3 to $4 \mathrm{~m}^{2}$, have a storage tank around 150-200 liters capacity (Kaygusuz \& Toklu, 2012; Kaygusuz, 2000, Bulut, 2004).

The situation in Turkey about sector features and potential can be summarized by some scholars as; the energy consumption of building for cooling and heating in Turkey was around 21.6 Mtoe in 2005. This consumption corresponds to more than $1 / 3$ of total energy consumption with that days' data. More than $\% 60$ of total energy consumption is used for space heating in households. In summer months, the cooling need in buildings increases mostly in south region of Turkey. Internal cooling and comfortable life requirements is thought to be the reason of weather conditions and building designs which can be called as general climatic and architectural boundary conditions. These issues present the great potential about thermal energy technologies in Turkey. Beside these, heat pumps and ground couples may be used for both cooling and heating of the building in the most regions of Turkey (Bilen et al., 2008, p.1556; Comaklı et al., 1993, Comaklı et al., 1996, Esen et al., 2006, Kaygusuz \& Toklu, 2012; Ozgerner \& Hepbaşl1, 2007, Dündar et al., 2002).

\subsection{Market Disadvantages}

Market disadvantages related to solar energy sector can be given in three subtitles. They are stated below in order of irregularities in the solar energy market, the dominated power of public sector and asymmetric information as result of unbalanced power of public sector.

\subsubsection{Irregularities in This Market}

As stated before there are some irregularities in this sector. One is that solar energy sector is far away from the position which it really deserves. Some examples can be given at this point. It is needed to increase $500 \mathrm{~kW}$ unlicensed electric production barrier to $1 \mathrm{MW}$. It is very important to encourage individual electric production. If this can be achieved, the sector will overcome an important obstacle by producing its own electricity in places such as houses, hotels, hospitals and industrial plants. Nonetheless, the sector has also disadvantages such as imperfect competition and the lack of well-qualified labor force. In addition, the sector has another disadvantage of tax in the sense of markets. In current usage, these energy systems gained acceptance in the category of luxuries goods, and \%18 VAT is applied on their sales. This situation makes underground economies existence unavoidable. For this reason the tax ratios should be decreased for this sector (Gündergi, 2013). 


\subsubsection{Dominated Power of the Public Sector}

The solar energy sector is closely related to political decisions. Liberalization and privatization in this sector are needed. Competition should be encouraged. Turkish bureaucracy causes some problems for investors. This barrier should be overcome and investors should feel comfortable in the market. If we give an example; initial capital, costs and management costs should be lowered, and private investors will be more attracted by this way. There should be subventions for local solar energy productions so that investment costs can be reduced by using new technology domestically (Kaya, 2006). For these reasons dominated power of public sector should be avoided as much as possible.

\subsubsection{Asymmetric Information}

One barrier for solar energy technology seems to be lack of co-operation and co-ordination between ministries, institutes, agencies and stakeholders. It will be good to make co-operation with some countries who dominates the market in solar energy policy areas, such as Germany, China etc. The energy supply and demand should be understood clearly. Straight forecasts should be taken account for the progress of liberalization, solar energy efficiency improvements, structural changes in industry and other major factors in order to better inform all players' investment decisions (Kaya, 2006). It is strongly needed to avoid from asymmetric information both within and outside the country.

\subsection{Market Failures: Lack of Competiveness}

The market failures can be taken as more comprehensive and detailed. On the other hand the things that should be done related to the solar energy markets current position at the beginning can be summarized as converting the situation of prices and making them functioning properly and letting subsidies reach its target by the objective decisions of Turkish government.

\subsubsection{Prices Are Not Signal}

According to the report entitled "The free market and the problems faced with its conductance" of Turkish Energy Council at the Turkish Union of Chambers and Commodity Exchanges (TOBB), the prices that is determined at the market conditions has not a property of signal. It is understood that the prices are not giving right signals to investors during the equilibrium of supply and demand in the market. As a result of this required investments cannot be made by investors. Report says that there is not any competition between public and private sector and this prevents prices to guide the market (Sağlam, 2012).

\subsubsection{Subsidies Are Not Reaching Its Goals}

In our energy policies, supporting regulations such as; heating from solar energy collectors, hot water and especially electrical energy production from solar energy (PV) are insufficient (Gündergi, 2013, p.28). Moreover, it can be said that subsidy policies are not sufficiently applied within the solar energy sector. Applying this policies and finding a solution to commercialization barriers are very important. Creating new technologies or transferring technology for renewable energy is more than necessary. But, these events should be done in detail and according to the country's needs (Kaya, 2006).

\section{Conclusion}

This paper presents one of the renewable energy markets in Turkey. Solar energy collector device and its market are chosen for this presentation. The type of the market is introduced thorough competition level. The current situation of the market in Turkey is discussed. The characteristics of the market, its barriers and problems of the sector are shown, and are summarized as follows.

There are some irregularities and asymmetric information in the market. Public sector dominates the market, and the competition level is not in sufficient level. Therefore, prices are not functioning and they cannot give signal for both sellers and buyers as they would have to be, and subsidies that are made by central government are not reaching their goals. To this end, some policy recommendations can be given in the following paragraph.

The role of the government in formulating and implementing favorable policies for renewable energy development is important. Competition should be encouraged by government. The private sector, which has the capacity to mobilize funds, needs to be involved in solar renewable energy development; therefore private sector should be encouraged. This will prepare a competition between public and private sector and prices can be a signal for investors as a result. At this point the government should be more careful and objective with its institutions such as EPDK. Government also should observe which preferences are possible with financial subventions and without financial subventions. So subsidies can be made at the most necessary circumstances. This may be the case for industry and university 
common studies and applications. By this corporation new renewable energy resources can be investigated and they can be used more efficiently. As a result the asymmetrical information in markets will be lost through the objective mediatorship of Turkish central government between public and private sectors.

This study is slightly different from other papers in the literature by narrowing its research area. While most of the studies in the literature reflect a general approach to renewable energy resources, this study strongly concentrates on flat plate solar energy collector markets (this specific approach is also seen in Ozsabuncuoglu (1995)). The basic problems that are observed in the market are taken consideration instead of solving an economic model in the study. Because, it is taught that, discussing an efficient economic model can only be possible after correcting current market failures.Therefore, the future studies' subject can be an economic model on flat plate solar energy collectors for competitive markets in Turkey after correcting all the market failures and redesigning the market.

\section{Acknowledgements}

We thank the anonymous referees for their helpful comments and crucial suggestions.

\section{References}

Bardhan, A., Jaffee, D., et al., (2014). Energy efficiency retrofits for U.S. housing: Removing the bottlenecks. Regional Science and Urban Economics, 47, 45-60. http://dx.doi.org/10.1016/j.regsciurbeco.2013.09.001

Baykul, M. C. (1987). Storing of solar energy. M.S. thesis, Anadolu University, Eskişehir, Turkey.

Bilen, K., Ozyurt, O., Bakırc1, K., Karslı, S., Erdoğan, S., Yılmaz, M., \& Comaklı, O. (2008). Energy production, consumption and environmental pollution for sustainable development: A case study in Turkey. Renewable and Sustainable Energy Reviews, 12, 1529-1561. http://dx.doi.org/10.1016/j.rser.2007.03.003

Bilgen, S., Keleş, S., Kaygusuz, A., Sarı, A., \& Kaygusuz, K. (2008). Global warming and renewable energy sources for sustainable development: a case study in Turkey. Renewable and Sustainable Energy Reviews, 12, 372-396. http://dx.doi.org/10.1016/j.rser.2006.07.016

Bulut, H. (2004). Typical solar radiation year for southeastern Anatolia. Renewable Energy, 29, 1477-1488. http://dx.doi.org/10.1016/j.renene.2004.01.004

Çetin, M., \& Egrican, N. (2011). Employment impacts of solar energy in Turkey. Energy Policy, 39, 7184-7190. $\mathrm{http}: / / \mathrm{dx}$. doi.org/10.1016/j.enpol.2011.08.039

Comakl1, O., Bayramoğlu, M., \& Kaygusuz, K. (1996). A thermodynamic model of a solar assisted heat pump system with energy storage. Solar Energy, 56, 485-92. http://dx.doi.org/10.1016/0038-092X(96)00005-9

Comakl1, O., Kaygusuz, K., \& Ayhan, T. (1993). Solar-assisted heat pump and energy-storage for residential heating. Solar Energy, 51, 357-66. http://dx.doi.org/10.1016/0038-092X(93)90148-H

Dündar, C., Canbaz, M., Akgün, N., \& Ural, G. (2002). Wind Atlas of Turkey. EIE, Electrical Power Resources Survey and Development Administration, Ankara, Turkey.

Esen, H., Inall1, M., \& Esen M. (2006). Technoeconomic appraisal of a ground source heat pump system for a heating season in eastern Turkey. Energy Conversation Management, 47, 1281-97. http://dx.doi.org/10.1016/j.enconman.2005.06.024

Gündergi. (2013). Yıl: 1 Sayı:1 Aralı $2012 \quad$ - Ocak-Şubat 2013. Retrieved from http://gunder.org.tr/wp-content/uploads/Gundergi-Sayi-1.pdf

Han, J., Mol, A. P. J., \& Lu, Y. (2010). Solar water heaters in China: A new day dawning. Energy Policy, 38, 383-391. http://dx.doi.org/10.1016/j.enpol.2009.09.029

Ilkılıç, C., Aydın, H., \& Behçet, R. (2011). The Current Status of Wind Energy in Turkey and in the World. Energy Policy, 39, 961-967. http://dx.doi.org/10.1016/j.enpol.2010.11.021

International Energy Agency (IEA). (2005). Energy policies of IEA countries: Turkey. Paris: IEA.

Kancs, A., \& Wohlgemuth, N. (2008). Evaluation of renewable energy policies in an integrated economic-energy-environment model. Forest Policy and Economics, 10, 128-139. http://dx.doi.org/10.1016/j.forpol.2007.06.003

Kaya, D. (2006). Renewable energy policies in Turkey. Renewable and Sustainable Energy Reviews, 10, 152-163. http://dx.doi.org/10.1016/j.rser.2004.08.001

Kaygusuz, K. (2000). Experimental and theoretical investigation of a solar heating system with heat pump. 
Renewable Energy, 21, 79-102. http://dx.doi.org/10.1016/S0960-1481(00)00003-3

Kaygusuz, K., \& Toklu, E. (2012). Energy issues and sustainable development in Turkey. Journal of Engineering Research and Applied Science, 1(1), 1-2. Retrieved from www.journaleras.com

Mankiw, N. G.. (2011). Principles of Economics (5th ed.). South-western Cengage Learning.

Manley, D. K., Hines, V. A., Jorda, M. W., \& Stoltz, R. E. (2013). A survey of energy policy priorities in the United States: Energy supply security, economics, and the environment. Energy Policy, 60, 687-696. http://dx.doi.org/10.1016/j.enpol.2013.04.061

Ministry of Energy and Natural Resources (MENR). (2005). Energy report of Turkey. Turkey: Ankara. Retrieved from http://www.enerji.gov.tr

Ozgener, O., \& Hepbasl, A. (2007). A review on the energy and exergy analysis of solar assisted heat pump systems. Renewable \& Sustainable Energy Reviews, 11, 482-496. http://dx.doi.org/10.1016/j.rser.2004.12.010

Özgür, M. A. (2008). Review of Turkey's Renewable Energy Potential. Renewable Energy, 33, 2345-2356. http://dx.doi.org/10.1016/j.renene.2008.02.003

Ozsabuncuoglu Ismail H. (1995). Economic analysis of flat platecollectors of solar energy. Energy Policy, 23(9). 755-763. http://dx.doi.org/10.1016/0301-4215(95)00063-O

Rizwan, M., Jamil, M., \& Kothari, D. P. (2010). Solar Energy Estimation Using REST Model for PV-ECS Based Distributed Power Generating System. Solar Energy Materials \& Solar Cells, 94, 1324-1328. http://dx.doi.org/10.1016/j.solmat.2009.01.014

Sağlam, E. (2012). Şeffaf, rekabetci piyasa ve bağımsı EPDK talebi. Retrieved from http://www.hurriyet.com.tr/yazarlar/20640218.asp

Timilsinaa, G. R., Kurdgelashvilib, L., \& Narbel, P. A. (2012). Solar energy: Markets, economics and policies. Renewable and Sustainable Energy Reviews, 16, 449-465. http://dx.doi.org/10.1016/j.rser.2011.08.009

Union of Chambers of Turkish Engineers and Architectures (UCTEA). (2012). Türkiye'nin Enerji Görünümü. Oda Raporu. MMO/588, Genişletilmiş İkinci Baskı.

Yarbay, R. Z., Güler A. Ş., \& Yaman, E. (2011). Renewable Energy Sources and Policies in Turkey. 6th International Advanced Technologies Symposium (IATS'11), 16-18 May, Elazığ, Turkey.

Yenilebilir Enerji Genel Müdürlüğü, (YEGM). Retrieved from http://www.eie.gov.tr/ 